\title{
PROGRAM KAMPUNG KELUARGA BERENCANA MENURUT HUKUM ISLAM
}

\author{
Nur Lailatul Musyafa'ah \\ Universitas Islam Negeri Sunan Ampel Surabaya Jl. A. Yani 117 \\ Surabaya.nurlailashafaa@gmail.com
}

\begin{abstract}
The KB village has several programs, namely Family Planning (KB), Tribina which includes Family Development Coaching, Adolescent Family Development, Elderly Family Development (BKB, BKR, and BKL), Efforts to Increase Prosperous Family Income (UPPKS), and Information and Counseling Center Youth (PIK_RM). Based on the analysis of Islamic law, the Family Planning $V$ illage program in general is in accordance with the principles of Islamic law, but there are a number of programs whose laws are disputed by Jurisprudence. The Tribina program is in accordance with Islamic law, because the obligation of parents to care for and educate their children from toddlers to adolescents is good, and caring for elderly parents is an obligation of children to their parents. Regarding the family planning program, the majority of scholars allow for the use of contraceptives not to be permanent, not harmful and carried out by experts, while the permanent contraception, such as vasectomy and tubectomy, the majority of scholars forbid them. In connection with the UUPKS, the legal UUPKS may even be recommended because part of mutual assistance. But what needs to be considered is that the business must be in accordance with the concept of Islamic business, including not containing elements of gharar (uncertainty) and usury. The PIK_RM is in accordance with Islamic law, because fostering teenagers with proper and good guidance is highly recommended in Islamic law, so that they can become a superior generation and not fall into bad things.
\end{abstract}

Keywords: Family Planning Village, Islamic law

Abstrak: Kampung KB memiliki beberapa program, yaitu Keluarga Berencana $(\mathrm{KB})$, Tribina yang meliputi Bina Keluarga Balita, Bina Keluarga Remaja, Bina Keluarga Lansia (BKB, BKR, dan BKL), Usaha Peningkatan Pendapatan Keluarga Sejahtera (UPPKS), dan Pusat Informasi dan Konseling Remaja (PIK_RM). Berdasarkan analisis hukum Islam, program Kampung KB secara umum telah sesuai dengan prinsip hukum Islam, namun ada beberapa program yang hukumnya diperselisihkan oleh fukaha. Program Tribina telah sesuai dengan hukum Islam, karena kewajiban orang tua merawat dan mendidik anaknya dari balita hingga remaja dengan baik, dan merawat orang tua yang sudah lansia merupakan kewajiban anak kepada orang tuanya. Mengenai program KB, mayoritas ulama membolehkan selama penggunaan alat kontrasepsi tersebut tidak bersifat permanen, tidak membahayakan, dan dilakukan oleh orang yang ahli, sedangkan alat kontrasepsi yang permanen, seperti vasektomi dan tubektomi, mayoritas ulama mengharamkannya. Berkaitan

AL-HUKAMA

The Indonesian Journal of Islamic Family Law Volume 08, Nomor 02, Desember 2018; ISSN:2089-7480 
dengan UUPKS, UUPKS hukumnya boleh bahkan dianjurkan karena bagian dari saling tolong menolong, namun yang perlu diperhatikan adalah usaha tersebut harus sesuai dengan konsep bisnis Islam, diantaranya tidak mengandung unsur gharar dan riba. Adapun PIK_RM, sesuai dengan hukum Islam, karena membina remaja dengan pembinaan yang benar dan baik sangat dianjurkan dalam hukum Islam, agar mereka bisa menjadi generasi yang unggul dan tidak terjerumus kepada hal-hal yang buruk.

Kata Kunci: Kampung Keluarga Berencana, hukum Islam.

\section{Pendahuluan}

Definisi Kampung KB pada Kamus Istilah Kependudukan dan KB yang diterbitkan oleh Direktorat Teknologi Informasi dan Dokumentasi (DIT'TIFDOK) pada tahun 2011 adalah salah satu upaya penguatan Program KKBPK yang dikelola dan diselenggarakan dari, oleh, dan untuk masyarakat dalam memberdayakan dan memberikan kemudahan kepada masyarakat untuk memperoleh pelayanan total program $\mathrm{KB}$, sebagai upaya mewujudkan keluarga yang berkualitas.

Berdasarkan pengertian tersebut diketahui, bahwa kampung $\mathrm{KB}$ selain mengatur program $\mathrm{KB}$, juga melakukan pembinaan terhadap keluarga, dan ekonomi keluarga.

Dibentuknya kampung KB didasarkan pada undang-undang sebagaimana berikut:

1. Undang-Undang Nomor 52 Tahun 2009 tentang Perkembangan Kependudukan dan Pembangunan Keluarga

2. Undang-Undang Nomor 23 tahun 2014 tentang Pemerintahan Daerah semakin mempertegas kewenangan tersebut, dimana pada lampiran Undang-Undang Nomor 23 tahun 2014 tentang Pembagian Urusan Pemerintahan Konkuren Antara Pemerintah Pusat, Daerah Provinsi dan Daerah Kabupaten/Kota pada huruf N (Pembagian Urusan Pemerintahan Bidang Pengendalian Penduduk dan Keluarga Berencana) menegaskan kewenangan dalam pelaksanaan urusan Pengendalian Pendudukan dan Keluarga Berencana antara Pemerintah, Pemerintah Provinsi dan Pemerintah Kabupaten/Kota. Empat sub urusan bidang pengendalian penduduk dan keluarga berencana yang harus dilaksanakan oleh masing masing tingkatan perintah yaitu; (1) sub urusan Pengendalian Penduduk, (2) sub urusan Keluarga 
Berencana, (3) sub urusan Keluarga Sejahtera, dan (4) sub urusan Sertifikasi dan Standarisasi.

Berdasarkan undang-undang di atas, pemerintah Indonesia menggalakkan program Kampung Keluarga Berencana yang lebih sering disebut dengan Kampung KB. Dalam program Kampung KB ini terdapat beberapa kegiatan yang berkaitan dengan keluarga yang meliputi orang tua, anak-anak, dan remaja. Selain itu terdapat kegiatan yang berkaitan dengan peningkatan ekonomi keluarga.

Negara Indonesia merupakan negara yang mayoritas berpenduduk muslim. Masalah KB merupakan masalah yang sering dibahas di dalam hukum Islam, yang kebanyakan membahas tentang hukum KB dalam arti membatasi jumlah anak. Dengan adanya program Kampung $\mathrm{KB}$ yang tidak hanya membahas tentang pembatasan jumlah anak, karena terdapat program lain yang berkaitan dengan pembinaan, tentunya menimbulkan masalah hukum baru yang perlu dikaji dan dibahas, sehingga program tersebut diketahui telah sesuai dengan hukum Islam atau tidak.

Berdasarkan hal tersebut, maka artikel ini membahas tentang Program Kampung Keluarga Berencana menurut hukum Islam.

\section{Program Kampung KB}

Kampung KB memiliki beberapa program, yaitu ProgramTribina yang meliputi Bina Keluarga Balita, Bina Keluarga Remaja, Bina Keluarga Lansia (BKB, BKR, BKL), Program Keluarga Berencana (KB), Usaha Peningkatan Pendapatan Keluarga Sejahtera (UPPKS), dan Pusat Informasi dan Konseling Remaja (PIK_RM). Berikut dijelaskan tentang program kampung Keluarga Berencana:

1. Program Tribina (Bina Keluarga Balita, Bina Keluarga Remaja, dan Bina Keluarga Lansia)

a. Bina Keluarga Balita

Pembangunan kesehatan sebagai bagian dari upaya membangun. Manusia seutuhnya antara lain diselenggarakannya melalui upaya kesehatan anak yang dilakukan sedini mungkin sejak anak masih di dalam kandungan. Upaya kesehatan ibu yang dilakukan sebelum dan semasa hamil hingga melahirkan, ditujukan untuk menghasilkan keturunan yang sehat dan lahir dengan selamat 
(intact survival). Upaya kesehatan yang dilakukan sejak anak masih di dalam kandungan sampai lima tahun pertama kehidupannya, ditujukan untuk mempertahankan kelangsungan hidupnya sekaligus meningkatkan kualitas hidup anak agar mencapai tumbuh kembang optimal baik fisik, mental, emosional maupun sosial serta memiliki intelgensi majemuk sesuai dengan potensi genetiknya.

Pengetahuan ibu mengenai stimulasi perkembangan anak sangat diperlukan, sehingga ibu dapat melakukan praktek pemberian stimulasi secara dini pada anak-anaknya. Sementara itu tidak semua ibu balita mengetahui apa itu stimulasi, apa itu kegunaannya dan bagaimana melakukannya, sehingga mereka kebanyakan hanya membiarkan anak tumbuh dan berkembang secara alami tanpa pengetahuanpengetahuan khusus.1

Menyadari akan pentingnya pembinaan tumbuh kembang anak sejak dini, sejak tahun 1984 Badan Kependudukan dan Keluarga Berencana Nasional (BKKBN) mencanangkan program Bina Keluarga Balita (BKB), dan tahun 1991 program ini menjadi Gerakan BKB.2

Berdasarkan Undang-Undang nomor 52 Tahun 2009 tentang Perkembangan Kependudukan dan Pembangunan Keluarga Pasal 47, mengamanatkan bahwa pemerintah dan pemerintah daerah menetapkan kebijakan pembangunan keluarga melalui pembinaan ketahanan dan kesejahteraan keluarga. Salah satu bagian dari program pembinaan ketahanan keluarga tersebut ialah Bina Keluarga Balita (BKB). Bina Keluarga Balita (BKB) merupakan salah satu program

1 Rustantina dan Dewi Elliana, "Hubungan Pengetahuan Ibu tentang Kartu Kembang Anak (KKA) dengan Praktek Stimulasi Perkembangan pada Balita 1-3 Tahun di Kelompok Bina Keluarga Balita (BKB) Puji Lestari RW I Kelurahan Ngijo Kecamatan Gunungpati Semarang”, Jurnal Kebidanan, Vol. 3 No. 2 Tahun $2014,49$.

2 Oktriyanto, "Partisispasi Keluarga Anggota Bina Keluarga Balita (BKB) dalam Pengasuhan dan Tumbuh Kembang Anak Usia 0-6 Tahun", Jurnal Kependudukan Indonesia, Volume 11 Nomor 2 Desember 2016, 134. 
yang bertujuan untuk meningkatkan pemahaman dan keterampilan ibu dalam pengasuhan dan pendidikan anak.3

Program Bina Keluarga Balita (BKB) sebagai salah satu bagian program Keluarga Berencana (KB) bertujuan untuk meningkatkan pengetahuan dan keterampilan orang tua dan anggota keluarga lainnya dalam membina tumbuh kembang anak balita sesuai dengan usia dan tahap perkembangannya.4 Dengan aktif mengikuti $\mathrm{BKB}$, diharapkan orang tua memiliki bekal yang cukup untuk membantu anak-anaknya menjalani masa balitanya dengan benar, baik, dan menyenangkan.5

b. Bina Keluarga Remaja

Berdasarkan data BKKBN (Badan Kependudukan dan Keluarga Berencana Nasional), dalam upaya membangun penduduk yang berkualitas maka pemerintah memberikan perhatian besar terhadap pembangunan sumber daya manusia. Salah satu upaya kebijakan pemerintah adalah membuat program GenRe (Generasi Berencana) yang dikembangkan dalam rangka penyiapan kehidupan berkeluarga bagi remaja sehingga mereka mampu melangsungkan jenjang pendidikan secara terencana, berkarir dalam pekerjaan secara terencana, serta menikah dengan penuh perencanaan sesuai siklus kesehatan reproduksi.

Program Bina Keluarga Remaja merupakan salah satu program yang dikembangkan oleh Badan Kependudukan Keluarga Berencana Nasional (BKKBN) dalam upaya menciptakan ketahanan keluarga dan mewujudkan peningkatan kualitas remaja sebagai implementasi UndangUndang Nomor 52 Tahun 2009, tentang Perkembangan Kependudukan dan Pembangunan Keluarga di mana dalam

3 Resti Fauziah, "Efektifitas Program Bina Keluarga Balita", http://jurnal.unpad.ac.id/share/article/view/13059/5949, Vol. 4 No. 1, 2014, 61.

4 Andri Wahyuni, et al, "Dampak Program Bina Keluarga Balita (BKB) Terhadap Tumbuh Kembang Anak Balita 6-24 Bulan", e-Jurnal Pustaka Kesehatan, vol. 2 (no. 1) Januari 2014, 80.

5 Oktriyanto, "Partisispasi Keluarga Anggota Bina Keluarga Balita (BKB) dalam Pengasuhan dan Tumbuh Kembang Anak Usia 0-6 Tahun”, 134. 
pengelolaan programnya didasarkan pada Peraturan Kepala BKKBN Nomor 109/PER/F2/2012. Program Bina Keluarga Remaja (BKR) ini merupakan salah satu kegiatan yang sangat strategis dalam mengupayakan terwujudnya Sumber Daya Manusia potensial melalui upaya meningkatkan pengetahuan dan keterampilan keluarga dalam mengasuh dan membina tumbuh kembang remaja melalui peran orang tua dalam keluarga.

Selain itu, dengan adanya program BKR ini diharapkan dapat mengatasi meningkatnya kecenderungan perilaku seks bebas dikalangan remaja. Kelompok Bina Keluarga Remaja adalah suatu kelompok/wadah kegiatan yang terdiri dari keluarga mempunyai remaja usia 10-24 tahun yang dilakukan untuk meningkatkan pengetahuan, sikap dan perilaku orang tua remaja dalam rangka pembinaan tumbuh kembang remaja dalam rangka memantapkan kesertaan, pembinaan dan kemandirian ber-KB bagi Pasangan Usia Subur anggota kelompok.6

Program Bina Remaja merupakan upaya meningkatkan pengetahuan, sikap, dan keterampilan orang tua dan anggota keluarga dalam membina remaja secara seimbang melalui komunikasi efektif antara orang tua dan anak remaja, baik secara fisik, intelektual, kesehatan reproduksi, mental emosional, dan moral spiritual.7

c. Bina Keluarga Lansia

Salah satu indikator keberhasilan pembangunan adalah semakin meningkatnya usia harapan hidup penduduk, yang menyebabkan jumlah penduduk lanjut usia semakin

6 Astri Alviani, "Implementasi Program Bina Keluarga Remaja oleh Badan Keluarga Berencana dan Keluarga Sejahtera (BKBKS) di Kecamatan Sungai Pinang Kota Samarinda”, eJournal Administrasi Negara, Volume 5, Nomor 3, 2017, 6503.

7 Mardiyono, "Pola Pengelolaan Bina Keluarga Remaja (BKR) di Provinsi Jawa Timur", Jurnal Cakrawala, Volume 10 Nomor 1 Juni 2016, 50. 
meningkat setiap tahunnya.8 Peningkatan usia harapan hidup terdapat tantangan bahwa ke depannya, Indonesia akan menghadapi tiga beban; meningkatnya angka kelahiran, meningkatnya beban penyakit (menular dan tidak menular, dan peningkatan angka beban tanggungan penduduk kelompok usia produktif terhadap kelompok usia tidak produktif. Ditinjau dari aspek kesehatan, lansia mengalami penurunan kesehatan baik secara alami atau karena penyakit. Oleh karena itu, sejalan dengan meningkatnya jumlah lansia, maka perlua adanya persiapan dan perencanaan berbagai program kesehatan bagi lansia.9

Lansia adalah suatu proses yang akan dialami manusia yang berusia panjang. Menurut Undang-undang RI Nomor 23 Tahun 1992 tentang Kesehatan pasal 19 ayat 1 bahwa manusia lanjut usia adalah seseorang yang karena usianya mengalami perubahan biologis, fisik, kejiwaan, dan sosial. Perubahan ini memberikan pengaruh pada berbagai aspek kehidupan. Oleh karena itu kesehatan manusia usia lanjut perlu diperhatikan dengan tetap dipelihara agar selama mungkin agar selama mungkin dapat hidup secara produktif sesuai dengan kemampuannya, sehingga dapat berperan serta dalam pembangunan. Manusia disebut lansia bila berusia sekitar 60 tahun ke atas,10 sebagaimana undang-undang Nomor 13 Tahun 1998 tentang Pemberdayaan Lanjut Usia.11 Pada

8 Junadi, "Penyuluhan Bina Kelompok Lansia (BKL) guna Mewujudkan Keluarga Lansia Tangguh di Kecamatan Malo Kabupaten Bojonegoro", Jurnal Ilmiah Administrasi Negara, 2.

9 Nurul Kamila, "Pengembangan Kelompok Bina Keluarga Lansia (BKL) dalam Mewujudkan Lansia Sehat di Desa Besuki”, --Skripsi--, (Surabaya: UIN Sunan Ampel, 2018), 1.

10 Citra Dwi Oktavia Saputri, Peran Bina Keluarga Lansia (BKL) dalam Meningkatkan Kesehatan Lansia melalui Taman Pendidikan lansia di RRW 11 Kepub Kelurahan Klitren Kecamatan Gondokusuman Kota Yogyakarta, Skripsi-Universitas Negeri Yogyakarta, 2017, 235.

11 Eka Zuni Lusi Astuti dan Tri Winarni, "Mendorong Partisipasi Bina Keluarga Lansia (BKL) dalam Mewujudkan Tujuh Dismensi Lansia Tangguh di Desa Sumbesari, Moyudan, Sleman", Jurnal Pengabdian Kepada Masyarakat, Volume 3 Nomor 2 Maret 2018, 131. 
undang-undang tersebut, lansia dibagi menjadi dua kategori; lansia potensial dan lansia tidak potensial. Lansia potensial adalah lansia yang masih mampu melakukan pekerjaan dan/atau kegiatan yang dapat menghasilkan barang dan/atau jasa, sedangkan lansia tidak potensial adalah lansia yang tidak berdaya mencari nafkah sehingga hidupnya bergantung kepada bantuan orang lain. Kedua bentuk lansia ini memerlukan penanganan yang berbeda sesuai dengan kebutuhan lansia tersebut.12 Lansia perlu diberdayakan dengan upaya meningkatkan kemampuan fisik, mental, sosial, pengetahuan dan keterampilan para lanjut usia siap didayagunakan sesuai kemampuan masing-masing.

Pada undang-undang Nomor 51 Tahun 2009 tentang kebijakan Pembangunan Keluarga melalui Pembinaan Ketahanan dan Kesejahteraan Keluarga pasal 47 C, peningkatan kualitas hidup lansia agar tetap produktif dan berguna bagi keluarga dan masyarakat dengan pemberian kesempatan untuk berperan dalam kehidupan keluarga.

Program Bina Keluarga Lansia (BKL) merupakan suatu wadah kegiatan yang dilakukan oleh keluarga yang memiliki lansia untuk mengetahui, memahami, dan mampu membina kondisi maupun masalah lansia dalam meningkatkan kesejahteraan lansia. Program ini bertujuan untuk meningkatkan kesejahteraan lansia, melalui kepedulian dan peran keluarga dalam mewujudkan lansia yang sehat, bertaqwa kepada Tuhan Yang Maha Esa, mandiri, produktif dan bermanfaat bagi keluarga dan masyarakat.

Layanan BKL ini diperuntukkan bagi keluarga yang mempunyai anggota lansia dan keluarga yang seluruh anggotanya lansia. Secara tidak langsung juga diperuntukan untuk perorangan, yaitu tokoh agama dan tokoh masyarakat, lembaga swadaya dan organisasi masyarakat, instansi pemerintah dan swasta, dan berbagai bidang disiplin ilmu yang terkait (dokter, bidan, perawat, psikolog). Mereka dibina dan diberi penyuluhan agar bisa melihat keadaan lansia di

12 Ibid. 
sekitarnya sehingga mampu merawat dan menciptakan lansia yang produktif sehingga bisa meningkatkan kualitas hidup lansianya.13

2. Program Keluarga Berencana

Banyak masalah kependudukan yang dihadapi bangsa Indonesia, di antaranya peledakan penduduk, meningkatnya penduduk usia muda, kepadatan penduduk yang tidak merata, terjadinya ketimpangan dan kesenjangan sosial dan tingkat kesejahteraan. Di satu daerah banyak kekurangan tenaga kerja, di daerah lain berlebihan tenaga kerja.

Salah satu upaya yang dilakukan pemerintah untuk mengurangi jumlah penduduk adalah dicanangkannya Keluarga Berencana (KB). Dalam Keluarga Berencana diidealkan sebuah keluarga hanya terdiri dari orang tua dan dua anak. Dengan hanya memiliki dua anak saja, diharapkan beban keluarga berkurang, sehingga dapat meningkatkan kesejahteraan keluarga. Orang tua dapat menyekolahkan anak-anaknya, dapat memenuhi semua kebutuhan anak-anak dan sebagianya.

Keluarga Berencana merupakan salah satu upaya mewujudkan kebahagiaan dan kesejahteraan keluarga. Tujuan utama dari Keluarga Berencana adalah untuk lebih meningkatkan kesejahteraan ibu dan anak. Dengan mengatur kelahiran, isteri banyak mendapat kesempatan untuk memperhatikan dan mendidik anak-anak disamping memiliki waktu yang cukup untuk melakukan tugas-tugas sebagai ibu rumah tangga. Di pihak lain suami tidak perlu direpotkan oleh tuntutan-tuntutan biaya hidup serta biaya pendidikan anak-anak. Lebih dari itu anak-anak akan mendapatkan perhatian yang cukup dari orang tua yang kelak dapat memberikan dampak positif bagi tumbuh kembang kepribadian anak, sehingga menjadi manusia yang sehat secara fisik, mental dan sosial sesuai dengan apa yang dikehendaki dan diperintah oleh agama menjadi anak yang sholeh.14

13 Hesti Nurmaslina, Peran Kader Bina Keluarga Lansia Gresif dalam Meningkatkan Kualitas Hidup Lansia di Desa Banjarmulya Kecamatan Pemalang Kabupaten Pemalang, -Skripsi-(Semarang: Universitas Negeri Semarang, 2017), 3-4.

14 Slamet Makmur, "Pelaksanaan Keluarga Berencana (KB) Terhadap Tingkat Kesejahteraan Keluarga”, Jurnal Ilmiah Pendidikan Geografi, 55. 
Pengertian Keluarga Berencana menurut UU No. 10 Tahun 1992 tentang Perkembangan Kependudukan dan Pembangunan Keluarga Sejahtera adalah upaya peningkatan kepedulian peran serta masyarakat melalui pendewasaan usia perkawinan (PUP), pengaturan kelahiran, pembinaan ketahanan keluarga, peningkatan kesejahteraan keluarga kecil, bahagia dan sejahtera.

Tujuan pokok dari program KB yaitu penurunan angka kelahiran yang bermakna. Guna mencapai tujuan tersebut maka ditempuh kebijaksanaan mengkategorikan tiga fase untuk mencapai sasaran yaitu, yang pertama adalah fase menunda/mencegah kehamilan. Fase menunda kehamilan bagi PUS dengan usia isteri kurang dari 20 tahun dianjurkan untuk menunda kehamilannya. Kedua adalah fase menjarangkan kehamilan. Periode usia isteri antara 20-30/35 tahun merupakan periode usia paling baik untuk melahirkan dengan jumlah anak 2 orang dan jarak antara kelahiran adalah 2-4 tahun. Ketiga adalah fase menghentikan/mengakhiri kehamilan/kesuburan. Periode umur isteri di atas 30 tahun, terutama di atas 35 tahun sebaiknya mengakhiri kesuburan setelah mempunyai 2 orang anak. Hal penting yang keempat yaitu mempertimbangkan tanda-tanda bahaya. Calon akseptor harus diberitahu/diajarkan tanda-tanda bahaya dari metode kontrasepsi yang sedang dipertimbangkan olehnya, terutama untuk calon akseptor pil oral dan IUD.15

Terdapat 7 macam alat kontrasepsi; 2 macam alat kontrasepsi pria (kondom dan vasektomi) dan 5 alat kontrasepsi wanita (Alat Kontrasepsi dalam Rahim/AKDR, Implant, Tubektomi, Suntikan, dan pil).16 Berikut penjelasan alat kontrasepsi tersebut:

a. Kondom

Kondom merupakan selubung/sarung karet yang dapat terbuat dari berbagai bahan, di antaranya lateks (karet), plastik

15 Silviana Kartika Sari, "Hubungan Konseling Keluarga Berencana (Kb) Dengan Pengambilan Keputusan Pasangan Usia Subur (Pus) Dalam Penggunaan Alat Kontrasepsi”, Bidan Prada: Jurnal Ilmiah Kebidanan, Vol. 1 No. 1 Edisi Desember $2010,42$.

16 BKKBN, Konseling Keluarga Berencana dan Kesehatan Reproduksi, (Surabaya: Pusyan GATRA, 2013), 3. 
(vinil), atau bahan alami (produksi hewani) yang dipasang pada penis saat hubungan seksual.17

b. Vasektomi

Vasektomi adalah tindakan penutupan (pemotongan, pengikatan, penyumbatan) kedua saluran mani yang terdapat di kantong zakar sehingga sel mani tidak keluar saat senggama. 18

c. AKDR

Alat Kontrasepsi dalam Rahim (AKDR) bekerja terutama untuk mencegah sperma dan ovum bertemu. AKDR membuat sperma sulit masuk ke dalam alat reproduksi perempuan dan mengurangi kemampuan sperma untuk fertilisasi. 19

d. Implant

Implant ada yang memiliki masa kerja 5 tahun dan ada yang daya kerjanya 3 tahun.

e. Tubektomi

Tubektomi atau steril wanita adalah membuntu tuba fallopi dengan cara memasang cincin silastik pada tuba, supaya sperma tidak bertemu dengan ovum.

f. Suntikan

Suntikan yang dapat menekan ovulasi. Suntikan ini sering menimbulkan gangguan haid terutama amenorea, bersifat sementara dan sedikit mengganggu kesehatan. Efek samping yang bisa terjadi adalah peningkatan berat badan, sakit kepala, dan nyeri payudara. Bersifat sementara, jarang terjadi, tidak berbahaya dan cepat hilang.

g. Pil

Pil KB bisa menekan ovulasi. Pada 3 bulan pertama penggunaan pil terkadang timbul mual, pusing, sakit kepala, nyeri payudara, serta spotting yang akan hilang sendiri.20

3. Usaha Peningkatan Pendapatan Keluarga Sejahtera (UPPKS)

17 Abdul Bari Saifuddin, dkk., Buku Panduan Praktis Pelayanan Kontrasepsi, (Jakarta: PT Bina Pustaka Sarwono Prawirohardjo, 2010), MK 17. 18 BKKBN, Konseling Keluarga Berencana dan Kesehatan Reproduksi,3. 19 Abdul Bari Saifuddin, dkk., Buku Panduan Praktis Pelayanan Kontrasepsi, MK-75. 20 BKKBN, Konseling Keluarga Berencana dan Kesehatan Reproduksi,4-5. 
Badan Kependudukan dan Keluarga Berencana Nasional (BKKBN) adalah salah satu institusi yang bertanggungjawab dalam hal pemberdayaan keluarga. Pelaksanaan program pemberdayaan ekonomi keluarga telah dikembangkan BKKBN melalui Usaha Peningkatan Pendapatan Keluarga Sejahtera (UPPKS) sejak tahun 1994.21 Hal tersebut berdasarkan Undangundang Nomor 52 Tahun 2009 tentang Perkembangan Kependudukan dan Pembangunan Keluarga pasal 48 ayat 1 bagian (f) yang menyatakan bahwa salah satu cara melakukan kebijakan pembangunan keluarga dalam rangka peningkatan kesejahteraan keluarga adalah dengan meningkatkan peluang dan akses penerimaan sumber daya ekonomi melalui usaha mikro keluarga.22

Terbentuknya kelompok UPPKS diawali pada 1979 dengan nama Kelompok Usaha Peningkatan Pendapatan Keluarga Akseptor (UPPKA), dan berubah menjadi UPPKS pada 1994 berdasarkan Undang-Undang Nomor 10 tahun 1992, yaitu tentang Perkembangan Kependudukan dan Pembangunan Keluarga Sejahtera dengan menghimpun sebanyak 5 (lima) hingga 10 (sepuluh) keluarga peserta KB yang melakukan kegiatan usaha keluarga secara perorangan maupun kelompok. Tujuan awal adalah agar pendapatan keluarga yang tergabung dalam UPPKS itu meningkat sekaligus memantapkan kesertaan mereka sebagai peserta keluarga berencana yang aktif.23

UPPKS adalah kelompok usaha ekonomi produktif, yang beranggotakan sekumpulan anggota keluarga yang saling berinteraksi dan terdiri dari berbagai tahapan Keluarga Sejahtera, baik pasangan usia subur yang sudah berKB maupun yang belum

21 Wycliffe T. H.,A. A Istri Ngurah Marhaeni, "Efektivitas Program Usaha Peningkatan Pendapatan Keluarga Sejahtera (UPPKS) di Kecamatan Denpasar Barat", Jurnal Ekonomi Kuantitatif Terapan, Volume 6 Nomor 2 Agustus 2013, 79. 22 Lilis Heri Mis Cicih, Program UPPKS dan Kegiatan Pemberdayaan Ibu-Ibu, https://www.bkkbn.go.id/po-content/uploads/info_demografi_fix_2017.pdf., 3.

23 Menara Simanjuntak, "Analisis Kelompok Usaha Peningkatan Pendapatan Keluarga Sejahtera di DKI Jakarta, 2014”, Binus Business Review, Volume 5 Nomor 2 November 2014, 602. 
ber-KB dalam rangka meningkatkan tahapan kesejahteraan dan memantapkan.

Anggota UPPKS terdiri dari pasangan usia subur, pasangan Keluarga Berencana, remaja, dan lanjut usia. Anggota UPPKS diutamakan dari keluarga pra sejahtera. Tujuan UPPKS adalah 1. Mengajak keluarga aktif bergerak dalam ekonomi produktif, 2. Mensosialisasikan pengelolaan keuangan keluarga, 3. Meningkatkan ketahanan dan kemandirian keluarga, dan 4. Mewujudkan keluarga kecil, bahagia dan sejahtera.24

Melalui program UPPKS, pemerintah memberikan bantuan penguatan modal yang bersifat pinjaman kepada masyarakat tersebut. Dengan pinjaman tersebut harapannya masyarakat penerima bantuan dapat menggunakan untuk menciptakan usaha baru maupun memperbesar modal atas usaha yang dimilikinya agar kesejahterannya meningkat. Bagi wilayah dengan tingkat kesertaan KB yang masih rendah, UPPKS juga memiliki daya ungkit terhadap masyarakat untuk meningkatkan kesertaan dalam program KB.25

Dalam praktiknya, kampung $\mathrm{KB}$ bekerjasama dengan $\mathrm{BKKBN}$ dalam peminjaman uang sebagai modal usaha anggota KB. Modal tersebut dikembalikan secara mencicil.

4. Pusat Informasi dan Konseling Remaja (PIK_RM)

Remaja merupakan masa peralihan dari masa kanak-kanak ke masa dewasa yang meliputi semua aspek perkembangan sebagai persiapan memasuki usia dewasa. Masa remaja berlangsung dari usia 12 tahun hingga 21 tahun dan dapat digolongkan sebagai:

a. Masa remaja awal (usia 12-15 tahun)

b. Masa remaja madya (usia 15-18 tahun)

c. Masa remaja akhir (usia 18-21 tahun)

Pada masa remaja ini ada perubahan yang terjadi di antaranya: perubahan fisik, perubahan kognitif, perubahan

24 "Usaha Peningkatakan Pendapatan Keluarga Sejahtera (UPPKS) agar Ekonomi Keluarga Kian Berdaya”, PPT. BKKBN.

25 Mardiyono, "Model Pengelolaan Usaha Peningkatan Pendapatan Keluarga Sejahtera (Uppks) Dalam Upaya Peningkatan Akseptor KB”, Jurnal Cakrawala, Volume 09 Nomor 2 Desember 2015, 37. 
emosi, perubahan sosial, perubahan minat, perubahan seksual, dan perubahan kemandirian dan tanggungjawab.26 Tujuan dari adanya BKR adalah terwujudnya Generasi Berencana (Genre) yaitu remaja yang berperilaku sehat, terhindar dari resiko Triad KRR (seksualitas, Napza, HIV/Aids), menunda usia pernikahan sampai benar-benar siap, dan punya rencana kehidupan berkeluarga untuk mewujudkan keluarga kecil bahagia sejahtera.27

Dalam masalah seks pranikah, remaja dibina agar menghindari perilaku seks pranikah. Perilaku seks pranikah adalah segala tingkah laku yang didorong oleh hasrat seksual yang dilakukan oleh dua orang, pria dan wanita, di luar perkawinan yang sah.

Pengetahuan tentang kesehatan reproduksi bagi remaja penting diberikan agar remaja memiliki informasi yang benar mengenai sistem, fungsi dan organ reproduksi. Dengan informasi yang benar, remaja memiliki sikap dan tingkah laku yang bertanggung jawab mengenai kesehatan reproduksi.

Pengetahuan dasar kesehatan reproduksi yang perlu diberikan kepada remaja adalah:

1. Pengenalan mengenai sistem, proses, dan fungsi alat reproduksi (aspek tumbuh kembang remaja)

2. Perlunya pendewasaan usia perkawinan (usia ideal menikah bagi perempuan 21 tahun dan laki-laki 25 tahun)

3. Infeksi menular seksual dan HIV/Aids serta dampaknya terhadap kondisi kesehatan reproduksi.

4. Bahaya penggunaan obat-obatan atau narkoba pada kesehatan reproduksi.

5. Pengaruh sosial dan media terhadap perilaku seksual.

6. Kekerasan seksual dan bagaimana menghindarinya.

7. Hak-hak reproduksi.

\section{Analisis Kampung Keluarga Berencana dalam Hukum Islam}

26 Pusat Pelayanan Keluarga Sejahtera, Bina Keluarga Remaja, (Surabaya: Pusyan Gatra, 2014).

27 Ibid. 
Di dalam Islam, tidak ada pembahasan khusus tentang kampung KB. Tetapi secara umum, agama Islam mengajarkan tentang konsep keluarga yang bahagia dan sejahtera. Islam juga mengajarkan tentang konsep mendidik anak dan ekonomi keluarga. 1. Analisis Hukum Islam terhadap Program Tribina

a. Bina Keluarga Balita dalam Hukum Islam

Pendidikan terhadap balita bisa dilakukan semenjak anak dalam kandungan, dengan cara ibu menjaga kesehatannya dengan nutrisi yang cukup, membiasakan perilaku yang karimah, menjaga emosinya dan lain sebagainya.28

Sesungguhnya Allah swt membuat variasi hukum-hukum yang diterapkan kepada manusia sejak kelahirannya hingga ketika menempati rumah keabadian. Di saat itulah segala bentuk ketentuan takdir Allah berlaku padanya hingga selesai. Ketika kemudian ia terpisah dari ibunya (lahir), maka hukumhukum amriyyah (yang bersifat perintah dan pembebenan) mulai menyentuhnya. Akan tetapi yang menjadi perantara untuk menerima perintah tersebut adalah kedua orang tuanya atau orang yang menggantikan kedudukan kedua orang tuanya sebagai pendidik dan pembina. Dalam kondisi tersebut, Allah memiliki hukum-hukum yang harus dijalankan oleh orang yang menjadi wali dari bayi tersebut. Selagi anak tersebut berada dalam asuhan dan tanggung jawabnya, maka dialah orang yang berkewajiban melaksanakan hukum-hukum tersebut.

Dalam Islam, kewajiban orang tua yang hendaknya dilakukan ketika anak lahir adalah menyampaikan kabar gembira dan ucapan selamat atas kelahiran, menyerukan azan di telinga bayi, tabnik (mengolesi langit-langit mulut), memberi nama, aqiqah, mencukur rambut dan bersedekah perak seberat timbangannya, dan khitan.29

Terdapat dua aspek penting yang harus ditanamkan kepada anak-anak dini usia, baik laki-laki maupun perempuan,

28 Zakiyah, "Pendidikan Anak Dalam Kandungan Perspektif Pendidikan Islam”, Islamadina, 2014, 1.

29 Yusuf Muhammad al-Hasan, Pendidikan Anak dalam Islam, (Makbtabah Abu Salma al-Atsari, e.book), 12-17. 
yakni aspek iman dan akhlak. Oleh karena itu, beberapa isyarat dan petunjuk tentang pendidikan anak sebagaimana yang dikisahkan dalam al-Qur'an QS. 31: 13, bahwa yang pertama diajarkan adalah tauhid (mengenal Tuhan) disusul kemudian dengan pendidikan akhlaq (QS. 31:14-17) menemukan relevansinya dengan potensi yang dimiliki anak.

Demikian juga nabi Muhammad sendiri ketika pertama kali mendidik umatnya juga menekankan aspek akidah baru disusul akhlak. Dengan pembiasaan yang baik sejak anak usia dini, akan sangat mempengaruhi dan bahkan membentuk pribadi muslim sebagaimana dicitakan oleh Islam. Dalam konteks inilah, maka orang tua berkewajiban untuk menggali dan mengembangkan potensi rohaniah anak melalui pendidikan shalat ketika anak usia tujuh (7) tahun dan memberikan peringatan keras mereka ketika sudah berusia sepuluh (10) tahun namun meninggalkannya, serta memisahkan ranjang antara anak laki-laki dan perempuan (HR. al-Tirmidzi). Dalam konteks hadits ini membiasakan dan mendidik kedisiplinan anak sejak usia dini menjadi penting dilakukan. Di samping itu, melatih anak agar potensi jasmaniahnya berkembang juga diisyaratkan agar orang tua mengajari anaknya (baik laki-laki maupun perempuan) berenang dan memanah (HR.al-Baihaqi). Dengan orientasi pendidikan yang demikian, diharapkan kedua aspek (jasmaniah-rohaniah) tersebut bisa berkembang secara beriringan. 30

Keluarga merupakan institusi yang pertama kali bagi anak dalam mendapatkan pendidikan dari orang tuanya. Jadi keluarga mempunyai peran dalam pembentukan akhlak anak, oleh karena itu keluarga harus memberikan pendidikan atau mengajar anak tentang akhlak mulia atau baik. Hal itu

30 Agus Purnomo, "Pendidikan Anak Dini Usia (Padu) dalam Islam: Sebuah Analisis Gender”, Egalita, Vol. 2 No. 2 Tahun 2007, 8-9. 
tercermin dari sikap dan perilaku orang tua sebagai teladan yang dapat dicontoh oleh anak.31

Mendidik anak dengan baik merupakan salah satu sifat seorang ibu muslimah. Dia senantiasa mendidik anak-anaknya dengan akhlak yang baik, yaitu akhlak Muhammad dan para sahabatnya yang mulia. Mendidik anak bukanlah (sekedar) kemurahan hati seorang ibu kepada anak-anaknya, akan tetapi merupakan kewajiban dan fitrah yang diberikan Allah kepada seorang ibu. Mendidik anak pun tidak terbatas dalam satu perkara saja tanpa perkara lainnya, seperti (misalnya) mencucikan pakaiannya atau membersihkan badannya saja. Bahkan mendidik anak itu mencakup perkara yang luas, mengingat anak merupakan generasi penerus yang akan menggantikan kita yang diharapkan menjadi generasi tangguh yang akan memenuhi bumi ini dengan kekuatan, hikmah, ilmu, kemuliaan dan kejayaan. 32

Berdasarkan hal tersebut, maka program bina keluarga balita sudah sesuai dengan hukum Islam. Orang tua dan keluarga berkewajiban merawat dan mendidik balitanya. Dengan mengetahui cara mendidik balita yang baik, orang tua diharapkan mampu merawat balitanya dengan baik, sehingga dapat memenuhi kebutuhan gizi dan pendidikan balita.

b. Bina Keluarga Remaja dalam Hukum Islam

Usia remaja yang berlangsung sekitar 9 tahun atau 14 tahun, adalah masa-masa di mana mereka sesungguhnya tengah mengalami sejumlah problema internal, baik dari aspek fungsi-fungsi reproduksinya maupun mentalnya. Banyak orang menyebut masa remaja sebagai masa transisi, masa mencari identitas diri dan sebutan lainnya. Masa transisi ini ditandai dengan perubahan-perubahan fisik, perubahan hormonal dan mulai berfungsinya organ-organ reproduksi yang segera mengantarkannya pada proses menstruasi, mimpi basah, jerawatan, bau badan, dan sebagainya.

31 A.Samad Usman, "Tanggung Jawab Orang Tua terhadap Pendidikan Anak dalam Perspektif Islam”, Bunayya: Jurnal Pendidikan Anak, Vol 1 No. 2 Tahun 2015, 118.

32 Ibid., 119. 
Perubahan-perubahan ini hampir selalu menjadi problem internal mereka yang tidak banyak diketahui orang lain. Ada ketakutan-ketakutan, kecemasan, keresahan, dan sebagainya yang menghinggapi mereka. Sangat disayangkan, banyak orang tua yang tidak memahami mereka pada saat-saat ini, remaja tengah membutuhkan perhatian, membutuhkan orang yang bisa menjadi wadah bagi keluh kesah dan keresahan mereka. Mereka butuh dipahami orang lain, terutama orang tuanya, bukan dimarahi dan disalahkan. Ketika orang tua tidak memahami problema tersebut dan ketika orang tua tidak bisa menjadi tempat mengadu dan menumpahkan keresahan dan kesulitan anak-anaknya, para remaja mencari pelarian ke ruang dan waktu yang lain. Hal yang membahayakan adalah manakala ruang dan waktu pelarian mereka tidak kondusif untuk menciptakan perilaku-perilaku positif dan produktif.

Bersama dengan hal di atas, ada pula problem di mana wacana keagamaan yang berkembang di sekitarnya juga memberikan tekanan-tekanan psikologis. Pada sisi lain, anakanak, termasuk remaja, wajib berbakti kepada orang tuanya, mereka harus menurut, dan taat kepada orang tuanya. Wacana keagamaan ini lalu diinterpretasikan sendiri oleh orang tuanya sesuai dengan kehendak dan kepentingannya tanpa meperdulikan hak-hak anak.33 Ini boleh jadi merupakan bentuk lain dari kekerasan terhadap mereka atas nama agama.

Dalam Islam, keluarga berperan penting dalam pembinaan remaja. Pengajaran tentang konsep bulugh dan implikasinya dalam ibadah, aurat, dan beriteraksi sesama manusia sebaiknya diajarkan melalui keluarga. Karena itu program Kampung KB yang berkaitan dengan bina keluarga remaja sesuai dengan prinsip hukum Islam. Dengan berperannya keluarga dan masyarakat dalam memperhatikan dan membimbing remaja dengan baik, diharapkan mampu menciptakan generasi bangsa yang unggul dan berkualitas.

c. Bina Keluarga Lansia dalam Hukum Islam

33 Ibid., 294-297. 
Orang tua memiliki jasa yang sangat besar terhadap anakanaknya. Begitu besarnya jasa orang tua terhadap anaknya, maka Allah mewajibkan kepada anak untuk berbakti kepada kedua orang tuanya. Bahkan dalam QS. Lukman ayat 14, berbakti kepada orang tua menempati kedudukan kedua setelah pengagungan kepada Allah swt. Begitu juga dalam QS. al-Isra' ayat 23, Allah menjelaskan tentang larangan melakukan perbuatan dan perkataan yang buruk kepada kedua orang tua.

Banyak cara dilakukan anak sebagai wujud berbakti kepada kedua orang tua, di antaranya: mentaati keduanya selain bermaksiat kepada Allah, berbuat baik, tawadhu', berkata halus, memberi makan, meminta izin ketika bepergian untuk jihad, memberi harta ketika mereka meminta, tidak bermuka buruk atau masam di hadapan keduanya, mendahulukan berbuat baik kepada ibu dibanding bapak, dan menduhulukan ibu daripada bapak.34

Berbakti kepada kedua orang tua memiliki keutamaan, yaitu: termasuk amalan yang mulia, merupakan salah satu sebab diampuninya dosa-dosa, salah satu penyebab masuk surga, merupakan sebab keridhoan Allah, merupakan sebab bertambahnya umur, dan merupakan sebab barokahnya rizki.35

Berdasarkan hal tersebut, maka program bina keluarga lansia tidak bertentangan dengan hukum Islam. Karena menghormati orang tua dan merawatnya dengan baik merupakan bagian dari kewajiban anak terhadap orang tuanya.

2. Analisis Hukum Islam Terhadap Program Keluarga Berencana

Keluarga berencana dalam Bahasa Arab berarti "tahdid alnasl" atau "tandzim al-nasl". Tabdid al-nasl terdiri dari dua kata yaitu tabdid dan al-nasl. Tabdid merupakan kata masdar dari kata kerja baddada yang berarti membatasi. Tabdid al-nasl berarti larangan

34 Faathimah Ummu Abdillah, "Anak Mengizinkan Orang Tua Lanjut Usia untuk Tinggal di Sasana Tresna Wherda", (Skripsi-Universitas Syarif Hidayatullah Jakarta, 2010), 3-4.

35 Mayasari, "Konsep Ikhsan Terhadap Orang Tua Menurut Imam Al-Ghazali", (Skripsi-Universitas Islam Negeri ar-Raniry Darussalam Banda Aceh, 2017), 11. 
melahirkan dengan berbagai macam cara, baik dengan ål, ta'qim, ijhadz, tabattul, larangan menikah, dan lain-lain.36

Dalam kaitannya dengan keluarga berencana, sesungguhnya al-Qur'an tidak berbicara langsung tentang keluarga berencana, namun hanya membicarakan kerangka etis bagi isu yang muncul.37 Menurut kalangan Islam yang mendukung KB, sikap diam al-Qur'an terhadap isu KB merupakan symbol persetujuan Islam. Tokoh yang berpandangan demikian antara lain adalah Fazlur Rahman. Menurut Rahman, ayat-ayat al-Qur'an yang perlunya mengontrol tingkat populasi kita dan perlunya mempersiapkan masa depan kita bersama tidak lain pada dasarnya adalah isyarat pentingnya dilaksanakan program KB. Namun pendapat yang demikian ini ditolak oleh sebagian kalangan Islam. Mereka menolak keberadaan KB. Abu A'la alMaududi, tokoh Islam garis keras, menyatakan bahwa ayat-ayat al-Qur'an dengan sangat jelas telah mengutuk praktik penguburan bayi perempuan yang baru lahir atau membunuh anak-anak, sebagaimana terdapat dalam Q.S. al-Takwir ayat (89), Q.S. al-Nahl ayat (57-59), Q.S. al-An'am ayat (137, 140, dan 151), Q.S. al-Mumtahanah ayat (13), dan Q.S. al-Isra ayat (31).

Ayat-ayat al-Qur'an yang disampaikan oleh kalangan Islam yang menolak KB dikritisi oleh Riffat Hassan, sebagaimana berikut:

a. Ayat-ayat al-Qur'an yang melarang pembunuhan terhadap anak kecil ditujukan kepada anak-anak yang sudah lahir, bukan kepada anak yang belum lahir.

b. Yang dimaksud dengan pembunuhan dalam ayat-ayat di atas tidak selalu dipahami sebagai pembunuhan yang sebenarnya akan tetapi merupakan penanganan untuk anak-anak kecil yang sedang sakit. Makna qatala tidak hanya membunuh

36 Muhammad Abdul Qadir, Tabdid al-Nasl wa al-Ijhadh fi al-Islam, (Yordan: Juhainah, 2003), 8.

37 Syafiq Hasyim, "Keluarga Berencana dalam Islam", dalam Abdul Moqsit Ghozali, Tubuh, Seksualitas, dan Kedaulatan Perempuan, (Yogyakarta: LKiS, 2002), 81. 
dengan senjata atau pukulan, akan tetapi juga merendahkan dan menurunkan derajat pendidikan dari yang semestinya. 38

Adapun bagi kalangan yang mendukung KB, Riffat memberikan catatan sebagaimana berikut:

a. Ketiadaan perang bukan berarti mengharuskan adanya kedamaian sebagaimana juga tidak adanya sakit tidak otomatis menandakan adanya kesehatan. Pada kenyataannya, al-Qur'an tidak menyatakan apa-apa melawan ide $\mathrm{KB}$, namun ini bukan berarti menyokong adanya $\mathrm{KB}$.

b. Masyarakat muslim sering mendengar bahwa al-Qur'an merupakan kitab yang memuat segala hal tentang kehidupan mereka. Mereka sangat berharap untuk menemukan pernyataan langsung dari ayat al-Qur'an yang menyinggung soal-soal yang penting bagi mereka. Ketika mereka tidak menemukannya, merka menyatakan bahwa al-Qur'an tidak menyatakan apa-apa tentang sebuah isu. Sikap diam al-Qur'an telah menciptakan kevakuman teologis dan etik yang oleh berbagai kalangan diisi dengan cara yang berbeda-beda. Maka dari itu, meskipun al-Qur'an tidak membicarakan persoalan $\mathrm{KB}$, namun persoalan seperti ini bisa diletakkan dalam sinaran kerangka etis Islam. Bahwa al-Qur'an membicarakan tentang hal-hal prinsip yang disebut dengan hak-hak manusia yang fundamental, seperti: 1) hak untuk dihormati sebagai manusia, 2) hak untuk diperlakukan adil dan setara, 3) hak untuk bebas dari tradisionalisme, otoritarianisme, tribalisme, klasisme, sistem kasta, seksisme, dan sistem perbudakan, 4) hak untuk menjaga diri dari penganiayaan, 5) hak untuk memperoleh ilmu pengetahuan, 6) hak untuk bekerja, 7) hak mendapatkan tempat tinggal yang aman, 8) hak untuk meninggalkan tempat tinggal karena di bawah tekanan, 9) hak untuk mengembangkan perasaan keindahan dan menikmati ciptaan Tuhan, 10) hak untuk mendapatkan kehidupan yang lebih baik.39

38 Ibid., 84.

39 Ibid., 86. 
Menurut Abu Zahrah, Islam menganjurkan pernikahan dan dalam proses pernikahan seorang laki-laki hendaknya mencari seorang wanita yang subur, yang bisa memiliki banyak keturunan. Hal tersebut tertera dalam al-Qur'an dan hadis.40

Di sisi lain, ada beberapa hadis yang membolehkan $a \approx l$ ada yang melarang a₹l.41 Di antara hadis yang membolehkan a₹l adalah:

Dari Jabir ia berkta; "Pada masa Nabi saw, kami pernah melakukan 'Azl (mencabut penis saat ejakulasi)." Telah menceritakan kepada kami Ali bin Abdullah Telah menceritakan kepada kami Sufyan Telah berkata Amru Telah mengabarkan kepadaku Atha` Ia mendengar Jabir ra berkata; Kami melakukan 'Azl, sedangkan Al Qur`an juga turun. Dan dari Amru dari Atha' dari Jabir ia berkata; Kami melakukan 'ą̨l di masa Nabi saw dan al-Qur`an juga turun."42

Di antara hadis yang melarang a

Telah menceritakan kepada kami 'Abdullah bin Yusuf telah mengabarkan kepada kami Malik dari Rabi'ah bin Abi 'Abdurrahman dari Muhammad bin Yahya dari Ibnu Muhairiz berkata; Aku melihat Abu Sa'id Al Khudriy ra lalu aku bertanya kepadanya tentang sesuatu, maka dia berkata: "Kami pernah keluar bersama Rasulullah saw pada perang Bani Al Mushtaholiq lalu kami mendapatkan tawanan dari keturunan 'Arab lalu kami tertarik dengan para wanita, namun pada saat yang sama kami juga masih ingin membujang dan menyukai melakukan 'azl (senggama terputus, coitus interuptus). Lalu kami tanyakan hal ini kepada Rasulullah saw, maka Beliau bersabda: "Tidak sebaiknyakah kalian tidak melakukannya, sebab tidak ada satu nyawapun yang telah Allah tetapkan akan muncul (jadi) hingga hari kiyamat kecuali dia pasti akan terjadi." 43

Berdasarkan perbedaan hadis tersebut, ulama berbeda pandangan tentang hukum $a \%$ :

40 Abu Daud, Sunan, Hadis Nomor 1754.

41 Abu Zahrah, Tandzim al-Usrah wa Tandzim al-asl, (Kairo: Dar al-Fikr al-Arabiy), 104.

42 Bukhari, Shabih, Hadis no 4808.

43 Ibid., hadis no. 2356. 
Pertama, Ibnu Hazm dan sebagian pengikut madzhab Hanbali membolehkan aql dan dianggap sebagai rukhsah fardiyyah (keringanan individu).44 Kedua, al-Ghazali mengatakan bahwa azl hukumnya makruh. Berdasarkan hadis:

Abu Bakr bin Abu Syaibah berkata, telah menceritakan kepada kami Yahya bin Ishaq berkata, telah menceritakan kepada kami Yahya bin Ayyub dari Muhammad bin 'Abdurrahman bin Naufal $\mathrm{Al}$ Qurasyi dari Urwah dari 'Aisyah dari Judamah binti Wahb Al Asadiah Bahwasanya ia berkata, "Aku mendengar Rasulullah saw bersabda: "Aku telah berkeinginan untuk melarang ghiyal (mensetubuhi isteri saat masih menyusui), namun ternyata orangorang Faris dan Yahudi melakukannya dan tidak membahayakan anak-anak mereka." Dan aku juga mendengar beliau ditanya tentang 'a₹l, beliau lantas menjawab: "Itu adalah pembunuhan yang terselubung." 45

Maka azl dianggap wa'd al-khafiyy berarti menunjukkan makruh bukan haram.

Ketiga, sebagian ulama mengharamkan aæl.46 Menurut Abu Zahrah, tabdid al-nasl menyalahi fitrah manusia, dan bertentangan dengan hadis shahih yang menganjurkan banyak anak, bertentangan dengan beberapa hadis yang melarang azl dan bertentangan salah satu maqashid al-syariah yaitu menjaga keturunan.47

Dengan perkembangan zaman, selain 'azl terdapat penggunaan alat kontrasepsi untuk mengatur atau membatasi keturunan. Ulama pun berselisih pendapat mengenai hal tersebut, begitu juga dengan ulama di tanah air. Mayoritas ulama membolehkan KB dengan menggunakan alat kontrasepsi selain vasektomi dan tubektomi.

Mengenai vasektomi dan tubektomi, Majelis Ulama Indonesia (MUI) dalam Keputusan Komisi Fatwa Tahun 1979 mengeluarkan fatwa haram terhadap vasektomi. Alasannya, pemandulan secara umum dilarang dalam agama. Selain di

44 Abu Zahrah, Tandżim al-Usrah wa Tandzim al-asl, 106.

45 Ibnu Majah, Sunan, dalam Aplikasi Kitam Sembilan, Hadis No 2001.

46 Abu Zahrah, Tandzim al-Usrah wa Tandzim al-asl, 107.

47 Ibid., 107. 
Indonesia, belum ditemukan dan dibuktikan jika vasektomi atau tubektomi dapat disambung kembali. Fatwa MUI saat itu ditinjau kembali dan dikuatkan pada 2009. Alasan peninjauan kembali fatwa tersebut adalah sudah ditemukannya cara menyambung kembali saluran sperma yang dipotong dalam proses vasektomi. Penyambungan kembali (rekanalisasi) ini bisa dilakukan oleh ahli urologi dengan menyambung saluran spermatozoa (vas deferen) melalui operasi. Namun, dalam temuan MUI berdasarkan penjelasan ahli ginekologi dari Universitas Indonesia, Prof Dr Farid Anfasa Moeloek, kemampuan untuk memiliki anak setelah rekanalisasi akan menurun. Penurunan kemampuan memiliki anak ini juga tergantung dari lamanya vasektomi yang dijalani.

Dengan dasar tidak ada jaminan kepulihan tingkat kesuburan setelah rekanalisasi, Komisi Fatwa MUI tetap memutus haram hukumnya melakukan vasektomi. Komisi Fatwa tetap mendasarkan hukumnya pada Q. S. al-An'am ayat (151) dan Q.S. al-Isra ayat (31).

Ulama dari Nahdlatul Ulama (NU) membatasi bolehnya penggunaan alat kontrasepsi selama tidak mematikan fungsi keturunan secara mutlak. Jika proses penjarangan kelahiran merusak atau menghilangkan bagian tubuh yang berfungsi, itu hukumnya haram. Dengan mengambil hukum bolehnya kontrasepsi sementara, ulama NU pada dasarnya juga memperbolehkan penggunaan spiral (IUD). Namun, syarat penggunaan IUD sangat ketat.

Majelis Tarjih Muhammadiyah dalam keputusannya tentang $\mathrm{KB}$ memberikan pandangan secara umum. Beberapa poin yang mesti diperhatikan menurut Majelis Tarjih adalah pencegahan kehamilan yang berlawanan dengan ajaran Islam jika niatnya memang segan memiliki anak. Selain itu yang dilarang juga merusak atau mengubah fisik, seperti memotong, mengikat, dan sebagainya. Melakukan penjarangan kelahiran diperbolehkan menurut Muhammadiyah jika ada kondisi darurat atas pertimbangan kesehatan. Namun, itu harus dengan persetujuan suami-istri dengan sudah meminta pertimbangan dokter ahli dan ahli agama. Kondisi darurat yang dimaksud diatas dijabarkan Majelis Tarjih dengan dua hal. Pertama, mengkhawatirkan 
kesehatan ibu karena mengandung atau melahirkan sesuai keterangan dokter. Kedua, mengkhawatirkan keselamatan agama akibat faktor kesempitan kehidupan, termasuk ekonomi, sehingga dikhawatirkan kaum Muslimin jatuh dalam menerima hal-hal yang haram dengan alasan memenuhi kebutuhan anak.48

3. Analisis Hukum Islam terhadap Usaha Peningkatan Pendapatan Keluarga Sejahtera (UUPKS)

Islam telah mengajarkan bahwa motivasi dan alasan bekerja adalah dalam rangka mencari karunia Allah swt. Tujuan bekerja adalah untuk mendapatkan harta agar seseorang dapat memenuhi kebutuhanya, menikmati kesejahteraan hidup dan perhiasan dunia. Pekerjaan yang dilakukan tersebut haruslah pekerjaan yang halal agar aktifitas bekerja ini juga bernilai ibadah.

Tentunya dalam pandangan Islam agar harta yang didapatkan dari bekerja tersebut menjadi kepemilikan yang sah. Bekerja bukan merupakan sebab mendapatkan harta melainkan perwujudan dari pelaksanaan perintah syara'. Sebagaimana Firman Allah SW'T dalam Q.S. al-Jumu'ah ayat (10): Apabila telah ditunaikan shalat, maka bertebaranlab kamu di muka bumi; dan carilah karunia Allah dan ingatlah Allah banyak-banyak supaya kamu beruntung.

Dalam Persfektif Islam, sistem perekonomian mengandung aturan-aturan Syara' yang dapat mengatur kehidupan perekonomian suatu rumah tangga, masyarakat, dan umat Islam secara keseluruhan. Ketentuan perekonomian Islam mencangkup peraturan tentang pendapatan, pengeluaran (pembelanjaan), penyimpanan, penabungan dan pemilikan. Ketentuan-ketentuan itu mengatur Perekonomian rumah tangga muslim agar dapat mewujudkan tujuan-tujuan umum hukum Islam, yaitu memelihara akal, agama, keturunan, kehormatan, dan

48 "KB Menurut Ulama Indonesia", https://www.republika.co.id/berita/koran/news-update/14/11/07/nenhso32kb-menurut-ulama-indonesia, diakses pada 6 September 2018. 
harta disamping agar dapat mewujudkan pemenuhan kebutuhan spiritual dan pemenuhan kebutuhan material.49

Keuangan rumah tangga sedikit banyak berasal dari konstribusi laki-laki atau suami sebagai kepala rumah tangga yang bertugas sebagai pencari nafkah, sedangkan adakalanya wanita hanya berperan sebagai pengelola keuangan. Namun, dewasa ini banyak wanita yang memainkan peran ganda dalam kehidupan rumah tangga yaitu sebagai pengelola dan juga sebagai penghasil keuangan baik itu sebagai wanita karier ataupun sebagai pengusaha. Sebagian perempuan menyatakan persamaan hak sebagai alasan mengapa mereka bekerja. Dalam kerangka emansipasi perempuan, sebagian istri bekerja menganggap bahwa peranan mereka dalam pembangunan bangsa dan negara tidaklah optimal kalau hanya sebagai ibu rumah tangga. Secara umum alasan perempuan bekerja adalah untuk membantu ekonomi keluarga. Keadaan perekonomian yang semakin tidak menentu, harga-harga kebutuhan pokok yang semakin meningkat, pendapatan keluarga yang cenderung tidak meningkat akan berakibat pada terganggunya stabilitas perekonomian keluarga.50

Kaum wanita saat ini tidak saja berperan tunggal, tetapi juga berperan ganda. Perkataan lain ibu rumah tangga tidak saja berperan pada sektor domestik, tetapi juga berperan di sector publik. Ibu-ibu rumah tangga yang bekerja di sektor publik, seperti: Berdagang keliling, berdagang kecil-kecilan, warung, pembantu rumah tangga, salon, pegawai, penjaga toko, buruh pabrik, berdagang di pasar dan sebagainya.

Pada masyarakat modern, tuntutan kehidupan saat ini semakin bertambah terutama bidang sosial dan ekonomi. Semua ini mengakibatkan status perempuan tidak lagi sebagai ibu rumah

49 Elfebriani, "Partisipasi Kaum Perempuan dalam Meningkatkan Pendapatan Keluarga menurut Perspektif Ekonomi Islam", (Skripsi-Universitas Islam Negeri Sultan Syarif Kasim Riau, 2011), 1-2.

50 Rahmah \& Hosen, "Peran Wanita dalam Upaya Peningkatan Pendapatan Rumah Tangga melalui Pembiayaan BMT (Studi Analisis pada BMT Berkah Madani Cimanggis)", Al-Infaq: Jurnal Ekonomi Islam, Vol. 5 No. 1, Maret 2014 , $1-2$. 
tangga saja, melainkan dituntut peranannya dalam berbagai kehidupan sosial kemasyarakatan, seperti turut bekerja membantu suami, bahkan untuk menopang ekonomi keluarga.51

Dalam agama Islam, perempuan dibolehkan bekerja selama pekerjaannya itu tidak menyampingkan keluarga, telah dijelaskan dalam kitab al-Qur'an (al-rijalu qawnamuna ala an-nisa). Dalam alQur'an dijelaskan bahwa "kaum laki-laki memperoleh bagian dari hasil usaha mereka dan kaum perempuan memperoleh pula bagian dari usaha mereka." Al-Qur'an menegaskan bahwa lakilaki dan perempuan sama-sama berhak memperoleh pekerjaan yang layak, sehingga mereka juga memperoleh upah kerja yang layak pula.52

Selain bekerja, suami istri dalam rumah tangga hendaknya pandai mengelola keuangan. Keuangan keluarga yang dikelola dengan baik akan menciptakan keharmonisan dan keluarga yang memuliakan Allah swt. Terkait dengan hal tersebut, al-Qur'an telah menyatakannya dalam beberapa ayat, antara lain dalam: (1) Q.S. 4 (an-Nisa'): 9, dinyatakan bahwa hendaklah takut orangorang yang sekiranya meninggalkan keturunan yang lemah di belakang mereka yang mereka khawatir terhadap kesejahteraannya. (2) Q.S. 2 (al-Baqarah): 240, dinyatakan bahwa orang-orang yang akan mati di antara kamu dan meninggalkan istri-istri, hendaklah membuat wasiat untuk istri-istrinya, yaitu nafkah sampai setahun tanpa mengeluarkannya (dari rumah). (3) QS. 59 (al-Hasyr): 18, dinyatakan bahwa orang-orang yang beriman hendaklah bertakwalah kepada Allah, juga setiap orang hendaklah memperhatikan apa-apa yang telah dipersiapkannya untuk hari esok. (4) QS. 5 (al-Maidah): 2, dinyatakan bahwa hendaklah kalian tolong-menolong dalam mengerjakan kebajikan dan takwa dan jangan tolong-menolong dalam berbuat dosa dan permusuhan.

51 Jeiske Salaa, "Peran Ganda Ibu Rumah Tangga dalam Meningkatkan Ekonomi Keluarga di Desa Tarohan Kecamatan Beo Kabupaten Kepulauan Talaud", Jurnal Holistik Tabun VIII No. 15 / Januari - Juni 2015, 2.

52 Sri Reskianti, "Peran Istri dalam Upaya Meningkatkan Perekonomian Rumah Tangga ditinjau dari Ekonomi Islam", (Skripsi-Universitas Islam Negeri Alauddin Makassar, 2017), 4. 
Hal-hal tersebut di atas adalah dasar-dasar hukum yang dapat digunakan untuk memberikan suatu solusi alternatif terhadap pengelolaan keuangan keluarga berdasarkan prinsipprinsip Islam. Jika keuangan keluarga tidak dikelola dengan baik maka keluarga tersebut secara finansial akan mengalami berbagai keterbatasan, dan tentunya akan mengakibakan tekanan emosional, mental, sosial, hubungan spiritual, dan malas meningkatkan potensi dan keterampilan, bahkan dapat menyebabkan perceraian dalam rumah tangga. 53

Berdasarkan hal tersebut, maka program mengembangkan ekonomi keluarga diperbolehkan dalam Islam. Namun, yang perlu diperhatikan adalah usaha tersebut terhindar dari hal-hal yang diharamkan dalam bisnis Islam, seperti riba dan gharar.

4. Analisis Hukum Islam terhadap Program PIK_RM

Ada sejumlah definisi yang diberikan orang untuk remaja. Departemen Kesehatan, misalnya, memberikan rumusan bahwa remaja adalah mereka yang berusia 10-19 tahun dan belum kawin atau nikah. Akan tetapi, belakangan rumusan tersebut berubah, karena usia 19 tahun ternyata tidak menjamin remaja telah menonjol kondisi yang sehat secara fisik, mental dan sosial untuk proses reproduksi, WHO kemudian meningkatkan cakupan usia remaja mejadi sampai berumur 24 tahun.

Definisi terakhir ini memperlihatkan bahwa faktor kesehatan dan kematangan reproduksi telah menjadi ukuran bagi keremajaan seseorang. Dan kesehatan reproduksi ternyata tidak hanya berkaitan dengan kondisi fisik atau mental yang tidak sakit, tetapi juga menyangkut kondisi sosialnya. Rumusan ini memperlihatkan adanya hubungan yang sangat erat, bahkan tak terpisahkan antara tiga unsur: fisik, mental, dan sosial. Ketiganya menjadi hubungan yang saling mempengaruhi. Kesehatan dengan begitu ternyata juga berarti sehat sosial.

Ada sejumlah pandangan yang perlu dikemukakan guna memberikan jalan keluar bagi problematika remaja di dalam keluarganya. Pertama, memberikan informasi yang benar kepada

53 Syaparuddin, "Pengelolaan Keuangan Keluarga Secara Profesional Dalam Mewujudkan Keluarga Sakinah", Al-Risalah-Jurnal Hukum Keluarga Islam, Volume 1 No. 1 Juli 2014, 193. 
mereka sehubungan dengan proses-proses perubahan yang sedang terjadi pada tubuh dan emosi mereka. Untuk hal ini, maka diperlukan pengetahuan yang cukup dari orang tua untuk dapat memahami fungsi-fungsi reproduksi dan hal-hal yang berkaitan dengan seksualitas mereka serta ada keterbukaan untuk membicarakannya.

Kedua, memberikan penghargaan, karena mereka sudah bukan anak-anak lagi, dan karena mereka merasa mampu berfikir dan mengambil keputusan untuk dirinya sendiri. Yang diperlukan orang tua adalah memberikan arah bagi kecenderungan positif mereka dengan argument yang dapat difahami.

Ketiga, memberikan perhatian yang sungguh-sungguh, karena mereka tengah mengalami perubahan-perubahan transisional pada aspek emosi yang tidak mereka sadari. Pada sisi lain, mereka juga tengah mencari kepribadian atas diri mereka sendiri. Yang diperlukan dalam hal ini adalah komunikasi yang baik dan terbuka dengan mereka, tidak melayaninya dengan cara emosional.

Keempat, memberikan pendampingan dan panutan yang mampu memberikan keteladanan bagi mereka. Keteladanan merupakan cara paling efektif dari orang tua terhadap anaknya.

Kelima, menciptakan ruang-ruang keluarga yang familier, ramah, dan ruang religious. Religiusitas tidak hanya dibatasi pada aktifitas keagamaan personal atau ritual semata, tetapi juga relasi antar personal di bawah kerangka kemanusiaan (akhlak karimah). 54

Berdasarkan hal tersebut, maka program PIK_RM sudah sesuai dengan hukum Islam. Bahwa para remaja harus mengerti apa yang sudah boleh dikerjakan dan yang tidak boleh dilakukan. Karena itu, demi kemaslahatan bersama maka pendampingan bagi para remaja sangat dianjurkan agar mereka menjadi generasi yang unggul, yang berguna bagi agama, nusa dan bangsa.

\section{Penutup}

Kampung KB adalah salah satu upaya penguatan Program KKBPK yang dikelola dan diselenggarakan dari, oleh, dan untuk

54 Husein Muhammad, Islam Agama Ramah Perempuan, 300-301. 
masyarakat dalam memberdayakan dan memberikan kemudahan kepada masyarakat untuk memperoleh pelayanan total program KB, sebagai upaya mewujudkan keluarga yang berkualitas. Kampung KB memiliki beberapa program, yaitu Keluarga Berencana, Tribina yang meliputi Bina Keluarga Balita, Bina Keluarga Remaja, Bina Keluarga Lansia, Usaha Peningkatan Pendapatan Keluarga Sejahtera (UPPKS), dan Pusat Informasi dan Konseling Remaja (PIK_RK). Berdasarkan analisis hukum Islam, program Kampung Keluarga Berencana secara umum telah sesuai dengan prinsip hukum Islam.

Dalam program Tribina; Bina Keluarga Balita, Bina Keluarga Remaja dan Bina Keluarga Lansia sudah sesuai dengan hukum Islam. Karena merawat, memberikan makanan bergizi dan memberikan pendidikan yang terbaik untuk balita dan remaja merupakan bagian dari kewajiban orang tua. Hal tersebut harus didukung dengan pemahaman orang tua tentang cara merawat dan mendidik anak dengan baik. Selain memperhatikan balita dan remaja, keluarga juga memperhatikan orang tua, khususnya yang sudah lansia, yang dalah Islam merupakan kewajiban bagi anak untuk berbakti kepada orang tua.

Dalam program $\mathrm{KB}$, ulama berselisih pendapat mengenai penggunaan alat kontrasepsi, yang mayoritas membolehkan penggunaan alat kontrasepsi yang tidak menghalangi kehamilan secara permanen dengan syarat-syarat tertentu, khususnya yang membutuhkan keahlian khusus dalam pemasangannya seperti implant, KB suntik, atau IUD. Adapun alat kontrasepsi yang bersifat permanen seperti vasektomi dan tubektomi, mayoritas ulama tidak membolehkannya.

UUPKS merupakan Usaha Peningkatan Pendapatan Keluarga Sejahtera. Dalam hukum Islam, melakukan usaha sangat dianjurkan, apalagi untuk membantu ekonomi keluarga. Usaha peningkatan ekonomi keluarga juga sangat dianjurkan sebagai bagian dari tolong menolong. Namun yang perlu diperhatikan dalam bisnis Islam adalah usaha harus memenuhi syarat dan rukun yang sesuai dengan bisnis tersebut. Dalam bisnis Islam dilarang melakukan usaha yang mengandung riba dan unsur gharar. Maka selama UUPKS tidak mengandung unsur yang haram, maka hukumnya diperbolehkan. 
Nur Lailatul Musyafa'ah: Program kampung Keluarga Berencana......

Adapun PIK-RM sudah sesuai dengan hukum Islam, karena membimbing remaja menuju kebaikan merupakan sebuah kebaikan dan menasehati dalam kebenaran sangat dianjurkan dalam Islam sesuai dengan QS. Al-Ashr: 3.

\section{Daftar Pustaka}

Abdul Bari Saifuddin, dkk., Buku Panduan Praktis Pelayanan Kontrasepsi, Jakarta: PT Bina Pustaka Sarwono Prawirohardjo, 2010.

Abu Zahrah, Tandzim al-Usrah wa Tandzim al-Nasl, Kairo: Dar al-Fikr al-Arabiy, t.t..

Agus Irianto, et. Al., "Komunikasi Interpersonal antara Orang Tua dan Anak Remaja serta Identitas Diri Remaja: Studi di Bina Keluarga Remaja Parupuk Tabing Koto Tangah, Padang, Sumatera Barat", Populasi, Volume 26 Nomor 1 Tahun 2018. Agus Purnomo, "Pendidikan Anak Dini Usia (Padu) dalam Islam: Sebuah Analisis Gender", Egalita, Vol. 2 No. 2 Tahun 2007. Andri Wahyuni, et al, "Dampak Program Bina Keluarga Balita (BKB) Terhadap Tumbuh Kembang Anak Balita 6-24 Bulan", e-Jurnal Pustaka Kesehatan, vol. 2 (no. 1) Januari 2014. Aplikasi Kitab Sembilan.

Astri Alviani, "Implementasi Program Bina Keluarga Remaja oleh Badan Keluarga Berencana dan Keluarga Sejahtera (BKBKS) di Kecamatan Sungai Pinang Kota Samarinda", ejournal Administrasi Negara, Volume 5, Nomor 3, 2017.

Audrey H. Brown, "Kesehatan Reproduksi Remaja", dalam Anna Glasier, dkk. Keluarga Berencana dan Kesehatan Reproduksi, Jakarta: EGC, 2005.

BKKBN Jawa Timur, Hindari Perilaku Seks Pranikah, Surabaya: BKKBN Jawa Timur, 2017.

Hari Keluarga Nasional XXV Tahun 2018, Surabaya: BKKBN Jawa Timur, 2018. , Konseling Keluarga Berencana dan Kesehatan Reproduksi, Surabaya: Pusyan GATRA, 2013.

Citra Dwi Oktavia Saputri, Peran Bina Keluarga Lansia (BKL) dalam Meningkatkan Kesehatan Lansia melalui Taman Pendidikan lansia di RRW 11 Kepub Keluraban Klitren Kecamatan Gondokusuman 
Kota Yogyakarta, Skripsi-Universitas Negeri Yogyakarta, 2017.

Eka Zuni Lusi Astuti dan Tri Winarni, "Mendorong Partisipasi Bina Keluarga Lansia (BKL) dalam Mewujudkan Tujuh Dismensi Lansia Tangguh di Desa Sumbesari, Moyudan, Sleman", Jurnal Pengabdian Kepada Masyarakat, Volume 3 Nomor 2 Maret 2018.

Elfebriani, "Partisipasi Kaum Perempuan dalam Meningkatkan Pendapatan Keluarga menurut Perspektif Ekonomi Islam", Skripsi-Universitas Islam Negeri Sultan Syarif Kasim Riau, 2011.

Faathimah Ummu Abdillah, "Anak Mengizinkan Orang Tua Lanjut

Usia untuk Tinggal di Sasana Tresna Wherda", SkripsiUniversitas Syarif Hidayatullah Jakarta, 2010.

Hanif Anshori, "Konsep Kewajiban Orang Tua Terhadap Anak Pada Masa Neonatal Menurut Ibnu Qayyim Al-Jauziyah", Skripsi-Universitas Muhammadiyah Surakarta, 2009.

Hesti Nurmaslina, Peran Kader Bina Keluarga Lansia Gresif dalam Meningkatkean Kualitas Hidup Lansia di Desa Banjarmulya Kecamatan Pemalang Kabupaten Pemalang, --Skripsi--Semarang: Universitas Negeri Semarang, 2017.

Husein Muhammad, Islam Agama Ramah Perempuan, Yogyakarta: LKiS, 2007.

Jeiske Salaa, "Peran Ganda Ibu Rumah Tangga dalam Meningkatkan Ekonomi Keluarga di Desa Tarohan Kecamatan Beo Kabupaten Kepulauan Talaud", Jurnal Holistik Tahun VIII No. 15 / Januari - Juni 2015.

Junadi, "Penyuluhan Bina Kelompok Lansia (BKL) guna Mewujudkan Keluarga Lansia Tangguh di Kecamatan Malo Kabupaten Bojonegoro", Jurnal Ilmiah Administrasi Negara.

Lilis Heri Mis Cicih, "Program UPPKS dan Kegiatan Pemberdayaan Ibu-Ibu”, https://www.bkkbn.go.id/pocontent/uploads/info_demografi_fix_2017.pdf.

Mardiyono, "Model Pengelolaan Usaha Peningkatan Pendapatan

Keluarga Sejahtera (Uppks) Dalam Upaya Peningkatan Akseptor KB", Jurnal Cakrawala, Volume 09 Nomor 2 Desember 2015. 
, "Pola Pengelolaan Bina Keluarga Remaja (BKR) di Provinsi Jawa Timur", Jurnal Cakrawala, Volume 10 Nomor 1 Juni 2016.

Mayasari, "Konsep Ikhsan Terhadap Orang Tua Menurut Imam AlGhazali", Skripsi-Universitas Islam Negeri ar-Raniry Darussalam Banda Aceh, 2017.

Menara Simanjuntak, "Analisis Kelompok Usaha Peningkatan Pendapatan Keluarga Sejahtera di DKI Jakarta, 2014", Binus Business Review, Volume 5 Nomor 2 November 2014.

Muhammad Abdul Qadir, Tahdid al-Nasl wa al-Ijhadh fi al-Islam, Yordan: Juhainah, 2003.

Nurul Kamila, "Pengembangan Kelompok Bina Keluarga Lansia (BKL) dalam Mewujudkan Lansia Sehat di Desa Besuki", -Skripsi--, Surabaya: UIN Sunan Ampel, 2018.

Oktriyanto, "Partisipasi Keluarga Anggota Bina Keluarga Balita (BKB) dalam Pengasuhan dan Tumbuh Kembang Anak Usia 0-6 Tahun", Jurnal Kependudukan Indonesia, Volume 11 Nomor 2 Desember 2016.

Pusat Pelayanan Keluarga Sejahtera, Bina Keluarga Remaja, Surabaya: Pusyan Gatra, 2014.

Rahmah \& Hosen, "Peran Wanita dalam Upaya Peningkatan Pendapatan Rumah Tangga melalui Pembiayaan BMT (Studi Analisis pada BMT Berkah Madani Cimanggis)", AlInfaq: Jurnal Ekonomi Islam, Vol. 5 No. 1, Maret 2014.

Resti Fauziah, "Efektifitas Program Bina Keluarga Balita", http://jurnal.unpad.ac.id/share/article/view/13059/5949, Vol. 4 No. 1, 2014.

Rustantina dan Dewi Elliana, "Hubungan Pengetahuan Ibu tentang Kartu Kembang Anak (KKA) dengan Praktek Stimulasi Perkembangan pada Balita 1-3 Tahun di Kelompok Bina Keluarga Balita (BKB) Puji Lestari RW I Kelurahan Ngijo Kecamatan Gunungpati Semarang", Jurnal Kebidanan, Vol. 3 No. 2 Tahun 2014.

A. Samad Usman, "Tanggung Jawab Orang Tua terhadap Pendidikan Anak dalam Perspektif Islam", Bunayya: Jurnal Pendidikan Anak, Vol 1 No. 2 Tahun 2015. 
Silviana Kartika Sari, "Hubungan Konseling Keluarga Berencana (Kb) Dengan Pengambilan Keputusan Pasangan Usia Subur (Pus) Dalam Penggunaan Alat Kontrasepsi”, Bidan Prada: Jurnal Ilmiah Kebidanan, Vol. 1 No. 1 Edisi Desember 2010.

Slamet Makmur, "Pelaksanaan Keluarga Berencana (KB) Terhadap Tingkat Kesejahteraan Keluarga", Jurrnal Ilmiah Pendidikan Geografi.

Sri Reskianti, "Peran Istri dalam Upaya Meningkatkan Perekonomian Rumah Tangga ditinjau dari Ekonomi Islam", Skripsi-Universitas Islam Negeri Alauddin Makassar, 2017.

Syafiq Hasyim, "Keluarga Berencana dalam Islam”, dalam Abdul Moqsit Ghozali, Tubuh, Seksualitas, dan Kedaulatan Perempuan, Yogyakarta: LKiS, 2002.

Syaparuddin, "Pengelolaan Keuangan Keluarga Secara Profesional

Dalam Mewujudkan Keluarga Sakinah”, Al-Risalah-Jurnal Hukum Keluarga Islam, Volume 1 No. 1 Juli 2014.

Wycliffe T. H.,A. A Istri Ngurah Marhaeni, "Efektivitas Program Usaha Peningkatan Pendapatan Keluarga Sejahtera (UPPKS) di Kecamatan Denpasar Barat", Jurnal Ekonomi Kuantitatif Terapan, Volume 6 Nomor 2 Agustus 2013.

Yusuf Muhammad al-Hasan, Pendidikan Anak dalam Islam, Makbtabah Abu Salma al-Atsari, e.book.

Zakiyah, "Pendidikan Anak Dalam Kandungan Perspektif Pendidikan Islam", Islamadina, 2014.

"KB Menurut Ulama Indonesia",

https://www.republika.co.id/berita/koran/news-

update/14/11/07/nenhso32-kb-menurut-ulama-indonesia, diakses pada 6 September 2018.

"Usaha Peningkatakan Pendapatan Keluarga Sejahtera (UPPKS) agar Ekonomi Keluarga Kian Berdaya", PPT. BKKBN. 